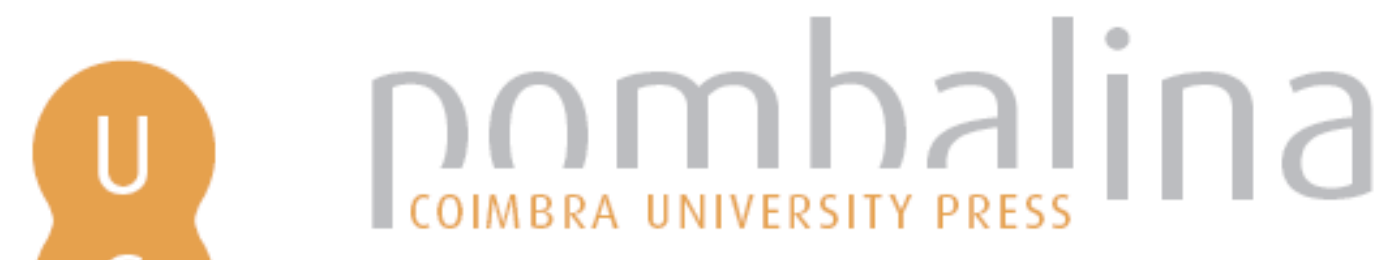

\title{
Nacionalismo e Pós-nacionalismo na Literatura Angolana: o Itinerário Pepeteliano
}

Autor(es): $\quad$ Venâncio, José Carlos

Publicado por: Imprensa da Universidade de Coimbra

URL

persistente: URI:http://hdl.handle.net/10316.2/32151

DOI: $\quad$ DOI:http://dx.doi.org/10.14195/978-989-26-0339-1_7

Accessed : $\quad$ 26-Apr-2023 10:30:44

A navegação consulta e descarregamento dos títulos inseridos nas Bibliotecas Digitais UC Digitalis, UC Pombalina e UC Impactum, pressupõem a aceitação plena e sem reservas dos Termos e Condições de Uso destas Bibliotecas Digitais, disponíveis em https://digitalis.uc.pt/pt-pt/termos.

Conforme exposto nos referidos Termos e Condições de Uso, o descarregamento de títulos de acesso restrito requer uma licença válida de autorização devendo o utilizador aceder ao(s) documento(s) a partir de um endereço de IP da instituição detentora da supramencionada licença.

Ao utilizador é apenas permitido o descarregamento para uso pessoal, pelo que o emprego do(s) título(s) descarregado(s) para outro fim, designadamente comercial, carece de autorização do respetivo autor ou editor da obra.

Na medida em que todas as obras da UC Digitalis se encontram protegidas pelo Código do Direito de Autor e Direitos Conexos e demais legislação aplicável, toda a cópia, parcial ou total, deste documento, nos casos em que é legalmente admitida, deverá conter ou fazer-se acompanhar por este aviso. 


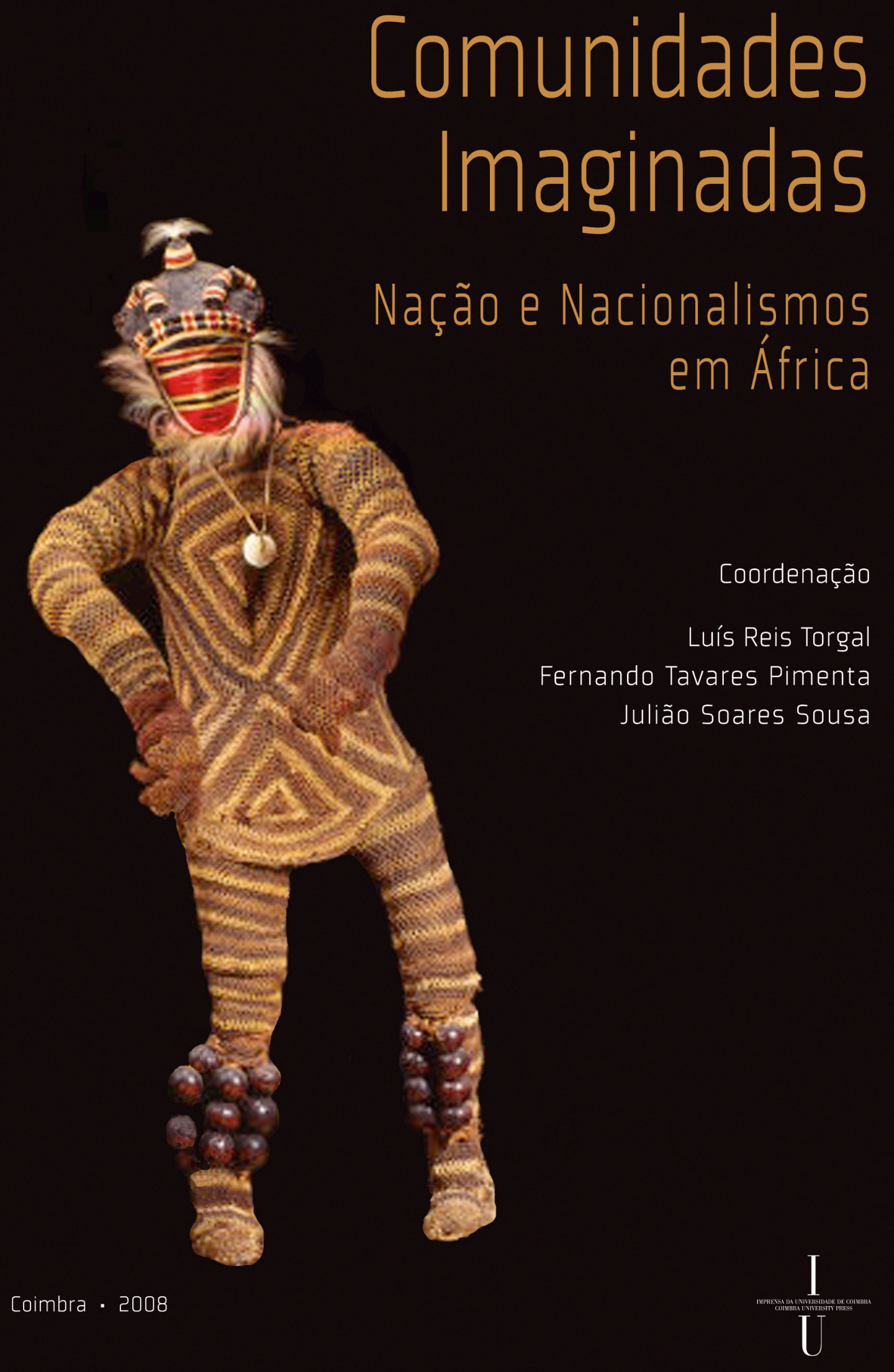




\title{
Comunidades Imaginadas \\ Nação e Nacionalismos em África
}

\author{
Coordenação \\ Luís Reis Torgal \\ Fernando Tavares Pimenta \\ Julião Soares Sousa
}

Coimbra $\cdot 2008$

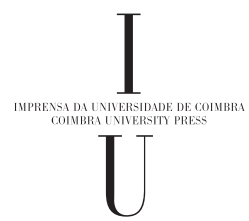




\begin{abstract}
COORDENAÇÃO EDITORIAL
Imprensa da Universidade de Coimbra

Email: imprensauc@ci.uc.pt

URL: http://www.uc.pt/imprensa_uc
\end{abstract}

CONCEPÇÃO GRÁFICA

António Barros

PAGINACÁO

Paulo Oliveira

[PMP]

EXECUÇÃO GRÁFICA

?????????????

ISBN

978-989-8074-57-7

DEPÓSITO LEGAL

????????????????????????

OBRA PUBLICADA COM A COLABORAÇÃO DE:

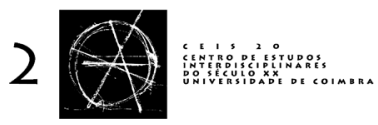

OBRA PUBLICADA COM O APOIO DE:

FCT Fundação para a Ciência e a Tecnologia

MINISTÉRIO DA CIÊNCIA, TECNOLOGIA E ENSINO SUPERIOR Portugal

Apoio do Programa Operacional Ciência, Tecnologia, Inovação do Quadro Comunitário de Apoio III 



\title{
José Carlos Venâncio
}

\section{NACIONALISMO E PÓS-NACIONALISMO NA LITERATURA ANGOLANA O Itinerário Pepeteliano}

"Wer keine Heimat mehr hat, dem wird wohl gar das Schreiben zum Wohnen".
Theodor W. Adorno ${ }^{1}$

\author{
"A minha pátria [...] é também aquela ilha caverna \\ dentro de mim \\ lugar onde \\ é possível revisitar sempre \\ O êxtase da fábula da infância [...]”
}

Maria de Lourdes Hortas ${ }^{2}$

O nacionalismo é definido por Gellner (1993: 11) como [...] "um princípio político que defende que a unidade nacional e a unidade política devem corresponder uma à outra”. A este princípio, ainda segundo o mesmo autor, serão redutíveis as acepçóes do conceito enquanto sentimento (a satisfação ou a cólera pela realização ou violação do princípio) e enquanto movimento (acção resultante de tal sentimento).

O chamado nacionalismo africano, no que é acompanhado pelo asiático, não se ajusta a esta definiçáo. $\mathrm{Na}$ sua esmagadora maioria, os países que ascenderam, por acção dos nacionalistas, à independência, na década de 60, dispunham de uma unidade territorial (a herança colonial), mas, de modo algum, de uma unidade nacional. $\mathrm{O}$ mesmo será dizer que a naçáo, enquanto comunidade de sentimento, era inexistente. Os nacionalistas, em situação de franca minoria, ao falarem na nação, evocavam fundamentalmente o seu sentido prospectivo. A sua existência era, assim, meramente discursiva. De tal forma o era que muitas foram as hesitaçóes quanto ao território e

\footnotetext{
${ }^{1}$ In Minima Moralia. Reflexionen aus dem beschädigten Leben (in textz.com), p. 71. "Quem já não tem pátria talvez até na escrita possa encontrar um lugar para morar”, tradução minha. Existe edição e tradução portuguesa deste livro: Minima moralia, Lisboa: Ediçóes 70, 2001.

2 Do poema "Navegaçôes (I)", in Fonte de pássaros (Recife 1999).
} 
às populaçôes a que a mesma haveria de corresponder aquando das independências e da formação dos novos Estados. Hesitaçôes destas ocorreram, por exemplo, nas negociaçóes para a formação da Federação do Mali, agrupando o Senegal e o Sudão Francês, que, devido precisamente a desinteligências entre os líderes nela envolvidos, acabou por não ir avante.

Perante estes condicionalismos, poder-se-á dizer que o nacionalismo africano, protagonizado por minorias ocidentalizadas, também chamadas elites coloniais, acaba por ter, em relação às mesmas, uma forte função catártica, de procura de uma identidade. Nesta medida, o nacionalismo em África vale como um movimento emancipalista do género do nativismo, da negritude e do pan-africanismo, lado pelo qual esse mesmo nacionalismo assume a sua especificidade máxima, afastando-se do asiático.

Em consonância com o sentido discursivo e catártico que o caracteriza, prevalece nele um sentido instrumental. É, enquanto tal, pensado a partir de um centro políticoadministrativo, sediado por norma na antiga capital colonial, que se transforma no fulcro da construção nacional.

O nacionalismo nas colónias portuguesas, com a excepção de Cabo Verde, não fugiu a este modelo, apresentando, porém, num registo que é praticamente extensível a todas as colónias, algumas diferenças que o particularizam no contexto do nacionalismo africano. Três parecem-me de particular importância.

A primeira tem a ver com o facto de os movimentos nacionalistas - sobretudo aqueles que se identificavam com uma linha de actuação mais socializante, agrupados à volta do CONCP (Conferência das Organizaçóes Nacionalistas das Colónias Portuguesas) - congregarem, no seu seio, brancos e mestiços. Sabe-se que nem sempre a emergência e a aceitação destas solidariedades por parte destes grupos humanos para com a maioria da população dessas colónias, que era negra, foi linear ou mesmo pacífica. Mas tais contratempos não foram suficientemente relevantes para impedir a sua existência e, consequentemente, a sua consideração neste registo académico.

A segunda característica específica prende-se com o facto de a palavra política nas colónias portuguesas ter sido antecedida e acompanhada pela palavra literária. Cabo Verde e Angola serão talvez as colónias onde este paralelismo atingiu maior significado. Sem que desta constatação se possa aferir obrigatoriamente qualquer relação de causalidade, o certo é que foram estas as únicas colónias onde se registaram, mesmo que de forma incipiente, movimentos modernistas. Estes, a par dos movimentos já referidos, de índole identitária negro-africana, a saber, o nativismo, a negritude e o pan-africanismo, proporcionaram, em muito, a consciencialização política nacionalista.

A terceira característica tem a ver com a inexistência de um movimento sindical com relevância política e ideológica em todas as colónias portuguesas. A vigência de um regime ditatorial na metrópole é, decerto, uma das explicações para tal situação. Diferentemente do que acontecia com as colónias inglesas ou francesas, de cujas hostes sindicais emergiram muitos dos nacionalistas de primeira geração (cf. os casos de Sékou Touré, na Guiné, e Houphouët-Boigny, na Costa do Marfim), na África de colonização portuguesa isso foi impossível. Outra explicação ainda poderá ser encontrada na fraca industrialização que se verificava nestas colónias aquando da emergência dos primeiros enunciados nacionalistas. 
A obra de Pepetela inscreve-se neste processo e dá dele um importante testemunho. Antes de passar, porém, à sua análise, numa perspectiva que é de sociologia da literatura, importa reter algumas consideraçóes de ordem metodológica. A realidade inferida será sempre, seguindo Wolfgang Iser (1993), uma realidade imaginada, produto de um acto criativo, onde está inscrita a condição antropológica do seu autor. Assim sendo, difícil será desligar a representação pepeteliana do processo histórico que conduziu à independência do país e à institucionalização do Estado pós-colonial da sua própria condição bio-somática, social e cultural. Quer isto dizer que a sua perspectiva desse processo e a sua participaçáo nele, enquanto nacionalista, guerrilheiro ou intelectual, esteve e está condicionada pela sua condição de não-negro, pela pertença a uma minoria que, se nâo será propriamente cultural, é vivencial; vivencial a partir de um estrato social e político privilegiado que, mesmo não partilhando a ideologia colonial, não a renegando publicamente, acabava, directa ou indirectamente, por usufruir do sistema e contribuir para a sua manutenção. Aproximo-me, em parte, com esta apreciação do papel dos estratos humanos e sociais mais identificados ou identificáveis com o poder colonial em Angola, das posiçóes de Frantz Fanon acerca da atitude dos intelectuais e democratas franceses na Argélia. Para este intelectual e activista político, o [...] "francês na Argélia não [...] podia [...] ser neutro ou inocente" (Fanon 1980: 90) ${ }^{3}$.

Aliás, a consciência desta situação fez com que Pepetela e muitos outros escritores e intelectuais angolanos de origem europeia se aproximassem e se integrassem no movimento, encetando processos que, sendo ou podendo ser, em termos políticoidentitários, de desalienação ${ }^{4}$, foram sobretudo de alienação em relação às suas origens. O "Poema da alienação" de António Jacinto, poeta agendado à chamada "geração de 50 ", é um exemplo contundente deste tipo de alienação, que não é, de modo algum, confundível com comiseração: [...] "o meu poema sou eu-branco / montado em mimpreto / a cavalgar pela vida" 5 .

Este mesmo processo, experimentado por Pepetela, consubstancia uma das duas vertentes ou dimensóes que caracterizam a sua obra. Refiro-me à dimensão que, na falta de melhor termo, designaria por introspectiva. A outra, em contraposição, será a extrospectiva.

A primeira, assentando numa procura identitária, começou por condicionar, em termos temáticos, a primeira obra de fôlego do autor. Refiro-me a Muana Puó (1978),

\footnotetext{
${ }^{3}$ Fanon, no seu radicalismo sui generis, que lhe valeu fervorosas críticas da parte da esquerda francesa, continua: "Qualquer francês na Argélia oprime, despreza, domina”. Os excertos em apreço fazem parte do capítulo "Os intelectuais e os democratas franceses perante a Revolução Argelina" do livro Pour la révolution africaine (1969), cuja edição portuguesa tem o título: Em defesa da revolução africana (1980). É este mesmo capítulo constituído por uma série de três artigos publicados em El Mondjahid (de 1, 15 e 30 de Dezembro de 1957).

${ }^{4}$ Tendo em conta o facto de pertencerem a estratos sociais que, não obstante a sua origem europeia, não deixavam de ser igualmente explorados e prejudicados pelo sistema colonial, quer na então metrópole, antes da emigração, quer em Angola.

${ }^{5}$ In A. Freudenthal, R. Magalhães, H. Pedro e C. Veiga Pereira (Org.), Antologias de poesia da Casa dos Estudantes do Império 1951-1963. Angola e S. Tomé e Príncipe (I Vol.), Lisboa: ACEI 2000: 152. Tendo sido esta uma atitude comum junto daqueles que, independentemente das suas origens europeias, resolvem inscrever o seu destino no de uma Angola libertada, algo utópica, seria interessante confrontá-la com o percurso de escritores brancos da África do Sul, tais como Nadine Gordimer e J. M. Coetzee.
} 
uma narrativa escrita em 1969, quando Pepetela se encontrava em Argel, na companhia de outros elementos do MPLA (Movimento Popular de Libertação de Angola). Trata-se, segundo o próprio autor, em entrevista concedida em 1989 (Venâncio 1992: 98), de um exercício de escrita que [...] "obedece a uma espécie de programa, um programa mínimo de tudo o resto”, ou seja, as ideias que posteriormente desenvolverá ao longo da sua obra estão, de certa forma, já aí inscritas.

Muana Puó ou mwana pwo é uma máscara ritual feminina dos tutchokwe, um grupo étnico-linguístico do Nordeste de Angola, que, embora usada apenas por homens, representará as mulheres antepassadas. No que à narrativa respeita, simbolizará, sobretudo, a cultura e os valores tradicionais que devem inspirar a Angola moderna, a pátria angolana, que ele e outros angolanos (negros, mestiços e brancos), numa atitude nacionalista em muito devedora das ideias negritudinistas e pan-africanistas, tomam como referência. Foi essa, aliás, a postura de Alexandre Semedo, personagem de um romance posterior, Yaka (1985), que é, de certa maneira, a saga da sua própria família. O romance, de cariz autobiográfico por conseguinte, relata a história de quatro geraçóes de uma família de colonos portugueses, em que Alexandre Semedo, representante da terceira geração, após muitas dúvidas e muitos monólogos em que questiona a sua identidade, opta, após a independência do país, pela nacionalidade angolana.

Em Lueji, o nascimento de um império (Luanda 1989/Lisboa 1990), romance igualmente marcado pela problemática identitária, é Lu, uma bailarina mestiça, provavelmente a sua própria filha, quem, nos finais do século XX, procura um sentido para a sua existência. Assume-se como descendente da mítica Lueji, a rainha fundadora do império Lunda. Reencarna-a, ou julga reencarná-la, quatro séculos depois. Une-as a reminiscência, no ano de 2000 , de uma das componentes da filosofia bantu: a de que os mortos, os antepassados, sobretudo os ilustres, convivem e condicionam o destino dos vivos. Através dos serviços de uma tia-avó, a tia Augusta, Lu entra em contacto com o espírito de Lueji, de quem recebe protecção para o empreendimento de levar ao palco do velho cinema Nacional um bailado sobre a mesma e a fundação do império Lunda.

A dimensão introspectiva é, sobretudo, evidente nos romances escritos durante a vigência do regime de partido único, em que o seu esforço de escrita se confundia, num plano subjectivo, com a procura de uma pátria (no sentido da Heimat de Ernst Bloch) ${ }^{6}$ e, em termos mais objectivos, com a instalação do socialismo e, por via dele, com a construção da nação angolana. Esta é pensada como uma utopia, como um espaço de igualdade, onde os conflitos raciais e étnicos, desde que a distribuição da riqueza fosse equitativa, seriam, se não inexistentes, pelo menos fortemente esbatidos. Trata-se, na

\footnotetext{
${ }^{6}$ Este filósofo alemão de influência marxista, nascido em Ludwigshafen em 1885 e que, em 1977, aos 92 anos de idade, morre depois de uma longa e atribulada vida, deixou, entre outras, duas obras de referência para o conceito de utopia: Geist der Utopie [Espirito da utopia (1923/1964)] e Das Prinzip Hoffnung [O princípio esperança (1959/1985)]. Para ele, utopia é uma realidade nunca alcançável, que, não sendo propriamente uma antecâmara para o paraíso, é passível de antecipação e de experimentação através da vivência quotidiana. Essa antecipação é, por sua vez, dificilmente compreensível fora de uma relação estética que viabilize a integração social (a relação sujeito-objecto/mundo interior-mundo exterior), na pressuposição de uma praxis duplamente desalienadora: do sujeito em relação a si próprio e deste em relação à natureza.
} 
verdade, de um conceito de raiz marxista, que, em última instância, radica num texto controverso do jovem ${ }^{7}$ Marx, escrito em 1843, Zur Judenfrage (A questão judaica). Nele, Marx, respondendo a Bruno Bauer, remete para a emancipaçáo humana a superação da discriminaçáo de que a comunidade judaica se sentia alvo na Alemanha.

Várias correntes do MPLA partilharam de tais assunçôes. Elas estão, por exemplo, na poesia de Agostinho Neto, conquanto possam ter aí outra origem, que não a propriamente marxista. Refiro-me nomeadamente à sua formação ou vocação evangélica, como Mário António Fernandes de Oliveira (1997: 295 e segs.) procurou demonstrar. Não seria igualmente despropositado afirmar que, não tendo sido tais assunçôes ou princípios obrigatoriamente observados na prática política do MPLA no período em apreço, os mesmos náo deixavam de constar do seu programa político, conquanto expressos em linguagem pragmática e simplificada. Só assim se entende, aliás, o surgimento, nos anos 80 (entenda-se, do século passado), de um conjunto de textos satíricos, consubstanciando uma corrente de sátira social na literatura angolana, pela pena de autores comprometidos com o regime ou, de forma menos reducionista, com a utopia por aquele sustentada. Refiro-me a Arnaldo Santos, com a novela Na M'banza do Miranda (Luanda 1984), a Manuel Rui, com Quem me dera ser onda (Luanda 1984), ao próprio Pepetela, com o romance $O$ cão e os caluandas (Lisboa 1985), e a Uanhenga Xitu, com O Ministro (Luanda 1990). As críticas em apreço incidiam sobre comportamentos de dirigentes e responsáveis médios, vulneráveis à corrupção e ao abuso do poder, práticas que contrariavam o rumo político superiormente definido.

De fora deste rol de autores fica Manuel dos Santos Lima, que cedo se afastou do MPLA e que, em 1984, publica o romance Os anóes e os mendigos, do qual se infere uma crítica contundente à conduta deste movimento e do seu líder, Agostinho Neto.

Um romance marca o fim deste período que, não tendo sido propriamente generoso, em termos sociais e políticos, para os angolanos, não deixou de patentear um lado idílico para Pepetela e para outros escritores, intelectuais e políticos da sua geração. Trata-se do romance $A$ geração da utopia (Lisboa 1992). Nele se descreve a desilusão, protagonizada, entre outros, por Aníbal ou Sábio (este, o nome de guerrilha), de certa maneira, um alter ego do próprio autor, como o já havia sido Sem Medo, o herói do romance Mayombe (1980).

Mayombe, o seu romance de estreia em termos de publicação, é, aliás, uma peça fundamental da vertente extrospectiva da sua obra. Atravessa-a um sentido pedagógico, por vezes, de um moralismo evidente, que se mantém, enquanto preocupaçáo de fundo, até aos mais recentes romances, como Predadores (2005) e O quase fim do mundo (2008). E, na verdade, de uma maneira geral, sem que daqui se possa inferir qualquer desmerecimento estético, nos romances pepetelianos o bem acaba sempre por prevalecer sobre o mal, o que pode ser entendido como uma herança marxista.

\footnotetext{
${ }^{7}$ Termo que refere a fase que se estende até à sua participação na Rheinische Zeitung (Gazeta da Renânia), onde assume em 1842 o posto de redactor-chefe. Nesta fase Marx afirma-se, sobretudo, como filósofo e é nele notória a influência - que, na verdade, nunca abandonará completamente - do idealismo de Hegel. Vale mencionar, contudo, que não se regista unanimidade entre os críticos e estudiosos de Marx quanto à separação da sua obra em duas fases: a da juventude e a da maturidade. Cf., por exemplo, a este respeito, Pires (1983: 139).
} 
Tal sentido pedagógico revestiu-se de um moralismo político acentuado, no género do realismo socialista, na novela As aventuras de Ngunga (1973), que começou por ser um conjunto de textos didácticos destinados aos pioneiros do movimento, a que o autor, mais tarde, em 1972, deu forma de livro. A incongruência que se regista na passagem da primeira para a segunda parte do livro, sendo que esta é mais imagética e complexa, ilustra precisamente as circunstâncias do seu aparecimento.

O mesmo sentido pedagógico, fruto da preocupação do revolucionário que quer transformar o mundo ou apenas construir uma pátria para todos, como foi, na verdade, até uma certa altura, o seu caso, está igualmente presente num romance, já citado, que se transformou numa das peças fundamentais da sátira social na literatura angolana. Refiro-me ao livro $O$ cão e os caluandas (1985).

Está igualmente presente no romance Lueji. O nascimento de um império (1990). Se em Yaka - como se verificou, um romance de teor autobiográfico, por conseguinte ilustrativo da dimensão introspectiva - era o elemento europeu que estava em causa, em Lueji é o passado pré-colonial, o elemento africano, que é valorizado. Sendo este, por força da estatística e dos paradigmas vigentes, determinante, na altura, em Angola e na restante África subsariana, ao evocá-lo, Pepetela aproxima-se de um exercício de escrita comum entre os seus congéneres africanos: o da valorização do passado précolonial. Lueji, enquanto personagem histórica, é, nestes termos, glorificada ao nível do que, por exemplo, aconteceu a Sundjata, o fundador do império Mali, no século XIII, no romance, de Djibril Tansil, intitulado de Sounjata, ou, l'épopée mandingue (1960). Mas as suas preocupaçóes pedagógicas, associadas a um irrepreensível rigor etno-histórico, vão mais longe, como o ilustra o seguinte excerto, suposta reacção do público ao verem o bailado de Lu:

[...] afinal este País teve gente assim e nós nem sabíamos, despojados que fomos da nossa História por séculos de obscurantismo, muitas vezes nos sonhando iguais aos outros mas sempre temerosos da comparaçấo, nada igualava as tradiçôes da Europa a que tínhamos de ficar para sempre agradecidos porque das trevas nos tirou [...] (p. 471).

Se em Lueji. O nascimento de um império, Parábola do cágado velho (1996) e, de certa maneira, na fábula $A$ montanha da água lilás (2000) é a valorização do passado pré-colonial que está em causa, no romance A gloriosa família (1997), para muitos críticos o seu melhor romance, é o passado colonial a ser questionado. O romance versa a história de uma das famílias "quatrocentonas” de Angola, descendentes de Baltazar Van Dum (leia-se Van-Dúnem), um holandês que, após a reconquista de Luanda por Salvador Correia de Sá, resolveu ficar e fixar residência na cidade. É em funçáo da história desta família que o autor revisita o passado colonial. Fá-lo munido de um instrumento analítico precioso do ponto de vista sociológico, que tanto é evidente neste romance, como, por exemplo, nos dois dedicados à figura de Jaime Bunda. Refiro-me ao conceito de grupo de status, devido a Max Weber e, na sua contextualização africana, a Immanuel Wallerstein (1972). Por ele se verifica que o lugar ocupado por esta família "alargada" na hierarquia social pós-colonial, em muito decorrente do lugar que haviam ocupado no período colonial, não é propriamente o de elite política, mas sim o de grupo de status, i.e., pertencendo a maioria dos seus membros a essa elite, muitos a ela 
não pertencem, o que não os impede de, a qualquer momento, por invocação do auxílio familiar, virem a ser guindados para o topo. E é o que, na verdade, acontece a Jaime Bunda:

Jaime encheu o peito. Finalmente começavam a reconhecer o seu mérito [...] até aí sempre esquecido, atirado para uma das cadeiras da sala de detectives sem nada para fazer, só porque era 'das famílias'. Chiquinho Vieira um dia mesmo lhe tinha dito que só o mantinha no serviço porque recebia ordens do D.O., o Director Operativo [...] que [...] era das famílias (p. 14).

Romances como O desejo da Kianda (1995), Jaime Bunda. Agente secreto (2001), Jaime Bunda e a morte do americano (2003) e, sobretudo, Predadores (2005), textos que consubstanciam, a par de outros, o que denominei de dimensão extrospectiva, são sobretudo significativos pela crítica que tecem ao curso político que a Angola "pós-utópica” tem encetado. E, desta feita, o poder político e as elites políticas não são poupadas na sua responsabilidade. Nem o Presidente da República, que durante anos governou o país a partir da sua residência no Futungo de Belas, está livre dessa crítica. Por exemplo, nos romances dedicados a Jaime Bunda, o "Futungo" é referido como Bunker, termo que tanto está associado a impunidade, como à Segunda Guerra Mundial, um dos momentos mais trágicos da história europeia e mundial. Mais contundente ainda é a crítica que, em Predadores, um romance que tanto tem de corajoso como de rigor analítico, é feita à nova burguesia, aos novos detentores do poder político e económico. Uma fria e calculada análise sociológica sobre a emergência dos novos poderes e sobre o capitalismo selvagem que se instalou no país náo teria sido mais efectiva no que respeita à desmontagem de todo um processo que, tendo muito a ver com a conjuntura internacional de globalização e de democratização dos regimes, foi, sobretudo, obra dos locais, dos antigos dirigentes (a um tempo marxistas) que, a dada altura, se converteram às delícias do capitalismo e da sociedade de consumo e se mantiveram, enquanto tal, no poder. Pepetela confirma, neste seu romance e, na verdade, em grande parte da sua obra, as afinidades que o discurso romanesco mantém, pelo menos em algumas das suas acepçóes, com o sociológico, que daquele emergiu, como Wolf Lepenies (1985) o demonstrou. Na circunstância pepeteliana justapóem-se.

A mensagem destes textos já não tem a ver com a necessidade de se construir uma naçáo ou a pátria angolana ou, ainda, com a necessidade de motivar e educar os seus conterrâneos nesse sentido, mas sim com a preocupação de mostrar que há alternativas à linha de desenvolvimento económico e social entretanto adoptada. Mesmo que o faça pela ironia, este sentido pedagógico não deixa de ser cumprido. No fim, Pepetela não mudou em relação àquilo que seria o seu propósito inicial, o sentido utópico da sua obra. Não obstante a desilusão manifestada no romance $A$ geração da utopia, continua a perseguir uma utopia, o da emancipação ou dignidade humana, a do homem desalienado, tal como esta problemática aparece em Marx e em teóricos por ele influenciados. Estou a lembrar-me da "Escola de Frankfurt" e da chamada teoria crítica, devida, entre outros, a Max Horkheimer e a Theodor Adorno, como também de Lucien Goldmann, não obstante o seu agendamento ao estruturalismo genético, de que foi fundador, ou ainda do já referido Ernst 
Bloch. A dignidade humana sobrepóe-se, nestes termos, à problemática da nação, ao nacionalismo, que é possível inferir da sua obra, pelo menos até à publicação de $A$ geração da utopia. O seu propósito orientador tanto está para além do nacionalismo, como para além das benesses que, a dada altura, a viragem para o capitalismo passou a beneficiar e a desviar os seus antigos correligionários dos princípios iniciais.

A par ou, talvez melhor, em complemento da defesa da dignidade humana, Pepetela introduziu novas batalhas, sendo uma delas a que se poderá traduzir por "desenvolvimento ecologicamente sustentado", um desenvolvimento que incorpore o sentido de vida do mundo rural e do mundo etnicamente integrado. É possível descortinar este sentido particular de desenvolvimento, por exemplo, no diálogo entre Vladimiro Caposso, o anti-herói do romance Predadores, e o advogado Sebastião Lopes, constituído como defensor dos pastores da Huíla, no Sul do país, que viram o acesso à água para o seu gado cortado pela vedação que Caposso mandou constuir para delimitar a fazenda de que se apossou por meios ínvios:

- A DECTRA contratou-te, é isso. Estranhamente, o nome da DECTRA não consta do processo.

- Nem inha que constar. Os queixosos são os criadores de gado, organizados em cooperativa perfeitamente legalizada.

- Cooperativa organizada pela DECTRA, claro...

- Talvez, não interessa. O trabalho das ONG’s é esse, não?

Pelo menos de algumas, das sérias. Mas que lhe importa se foi a DECTRA ou não? Que problema é que tem com a DECTRA?

- Porque são eles que andam a agitar os pastores contra mim, porra.

- Deixe disso. Os pastores não estariam agitados se o senhor não lhes tapasse os caminhos com o seu arame farpado. Quem os agitou foi o senhor. Não culpe agora os outros pelos seus erros (pp. 342-3).

Outras mensagens poderão ainda ser inferidas do excerto. O "luandocentrismo" [não obstante Caposso não ser nem luandense genuíno, nem catetense (de Catete ${ }^{8}$ ), como fazia crer] é uma delas.

Com a conquista de novas causas, assiste-se a uma progressiva internacionalização dos conteúdos e dos referentes das narrativas. A apreciação que o autor faz às ONG's, no excerto acima transcrito, é um exemplo desse alargar de horizontes, que, provavelmente, terá também a ver com a procura de novos públicos. A novela $O$ terrorista de Berkeley, Califórnia (2007), uma sátira à febre anti-terrorista que se apossou do mundo ocidental e, em particular, dos Estados Unidos da América após o 11 de Setembro, está na linha deste esforço de internacionalização. O seu último romance $O$ quase fim do mundo

\footnotetext{
${ }^{8}$ Cidade que dista cerca de $60 \mathrm{Km}$ de Luanda, para Nordeste, donde é originário Agostinho Neto e muitos outros importantes dirigentes do MPLA. Antes da independência já se associava o nome de Catete a um dos focos do nacionalismo. Após a independência vulgarizou-se a expressão "grupo de Catete" em alusão a um hipotético grupo de pressão constituído por tais dirigentes.
} 
(2008) é outro exemplo de que, não abdicando dos princípios que informaram a fase (mais) nacionalista, os aplica, desta feita, a causas que, pela sua própria natureza, são de maior impacto internacional.

Bem - tentando agora decalcar a ironia do autor - , chega a uns mais do que a outros. Da mesma forma que no processo de globalizaçáo se assiste a uma crescente marginalização da África subsariana, na destruição do mundo descrita neste romance, da responsabilidade de uma seita religiosa ciosa dos seus valores caucasianos, os mesmos se esqueceram de dosear devidamente a África subsariana com sua mortífera arma de destruição maciça, o "Feixe Gama Alfa", [...] "a mais limpa arma de todos os tempos" (p. 340), diz o autor. E de tal negligência resultou que os únicos sobreviventes da humanidade se localizassem precisamente na massacrada regiáo dos Grandes Lagos. “- Ironia? [...] interroga-se e comenta o médico Simba Ukolo, o herói do romance [...] - O mais desprezado dos sítios, África, é o que acaba por guardar a vida?" (p. 349).

O romance é uma alegoria onde é possível descortinar uma contundente crítica à actual ordem internacional, imposta pelos Estados mais poderosos, pelas economias mais industrializadas à restante humanidade, ignorando os mesmos que, tal como a serpente que morde a sua própria cauda ou o feitiço que se vira contra o feiticeiro, também eles acabarão por sucumbir perante a avidez dos seus actos e dos seus propósitos. São as ideias de desenvolvimento e de progresso, enquanto conceitos de extracção ocidental, que são aqui postos em causa. A grande mensagem do livro será, pois, a de que não será por aí o caminho. E não o é, porque por ele simplesmente se esquece da dignidade humana.

A titulo conclusivo, começaria por relevar o facto de o trajecto literário de Pepetela se inscrever, como nenhum outro, na história recente de Angola e dela dar, em consonância, um particular testemunho, quer no que respeita ao processo político que conduziu o país à independência, quer no que se refere ao rumo seguido após esse importante evento. O período pós-colonial é ainda passível de ser subdividido em dois sub-períodos: o do regime de partido único, em que o MPLA se assumiu como o único partido/movimento a gerir os destinos do país e o que, por volta de 1992, se lhe seguiu, marcado este pela liberalização política e, no que à economia concerne, pela abertura desta ao capital internacional. O primeiro sub-período é igualmente referido como período ou fase de (re)construção nacional, enquanto que o segundo, correspondendo a uma conjuntura despoletada pelo fim da Guerra Fria e pela emergência do fenómeno da globalização, decorre, para alguns, sendo de sob a égide do capitalismo selvagem (Hodges 2002).

A obra, em si, é, como vimos, passível de ser olhada sob duas vertentes ou dimensóes: a introspectiva e a extrospectiva. Nas narrativas agendadas à dimensão instrospectiva, numa postura que é sobretudo evidente durante a fase de (re)construçáo nacional, i.e. antes da publicação de $A$ geraçáo da utopia (1992), a sua escrita surge, num plano subjectivo, identificada com a procura de uma pátria, de uma Heimat, nas palavras de Ernst Bloch, o que, em termos concretos, se traduz na intenção de o autor se integrar no espaço político e identitário em construção.

Se tal problemática identitária foi, sobretudo, evidente no período histórico em apreço, náo deixou a mesma de acompanhar, com outros matizes e horizontes, a obra 
até aos dias de hoje. Na verdade, Pepetela - o que, por exemplo, não acontece com o escritor sul-africano J. M. Coetzee - nunca deixou de olhar o mundo a partir de Angola e de África, mesmo quando as suas preocupaçóes se deslocam de um registo meramente nacional para um plano mais internacionalizado, como acontece com os últimos romances.

A dimensão extrospectiva, nomeadamente o sentido pedagógico que é possível inferir dos textos, está presente, com igual ponderação, ao longo de toda a obra, mesmo naquela em que o autor é mais crítico e satírico. Como referi a dada altura da análise, há sempre uma luz ao fundo do túnel no discurso pepeteliano; subjaz-lhe um sentido escatológico, uma dádiva, porventura marxista, que lhe confere intemporalidade e enriquecimento estético.

\section{Bibliografia}

CARVALHO, Paulo de, 2002, Angola, quanto tempo falta para amanha? Reflexóes sobre as crises politica, económica e social, Oeiras: Celta Editora.

FANON, Frantz, 1980 [1969], Em defesa da revolução africana, Lisboa: Livraria Sá da Costa Editora.

GELLNER, Ernst, 1993 [1983], Naçôes e nacionalismo, Lisboa: Gradiva.

HODGES, Tony, 2002, Angola. Do afro-estalinismo ao capitalismo selvagem, Lisboa: Principia.

ISER, Wolfgang, 1993, Das Fiktive und das Imaginäre. Perspektiven literarischer Anthropologie, Frankfurt a. M.: Suhrkamp.

LEPENIES, Wolf, 1985, Die drei Kulturen. Soziologie zwischen Literatur und Wissenschaft, Munique: Carl Hanser Verlag.

OLIVEIRA, Mário António Fernandes de, 1997, A formação da literatura angolana (1851-1950), Lisboa: Imprensa Nacional-Casa da Moeda.

PIRES, Francisco Videira, 1983, Marx e o Estado, Porto: Lello \& Irmão - Editores.

VENÂNCIO, José Carlos, 1992, Literatura e poder na África lusófona, Lisboa: Ministério da Educação / ICALP.

WALLERSTEIN, Immanuel, 1972, "Social conflict in post-independence BlackAfrica: the concepts of race and status-group reconsidered”, in Ernest O. Campbell (Ed.), Racial Tensions and National Identity, Nashville: VanderbiltUniversity Press: 207-226. 



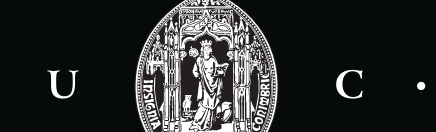

